\title{
COMPARATIVE STUDY ON THE PHYSICO-CHEMICAL, TEXTURAL AND THERMAL PROPERTIES OF INSTANT PORRIDGES BASED ON SPELT AND OATS
}

\author{
Olivera D. Šimurina*, Bojana V. Filipčev, Boško D. Marić, Biljana R. Cvetković, \\ Marija I. Bodroža Solarov \\ University of Novi Sad, Institute of Food Technology, 21000 Novi Sad, Bulevar cara Lazara 1, Serbia
}

${ }^{*}$ Corresponding author:

Phone: +381214853778

E-mail address: olivera.simurina@fins.uns.ac.rs

\begin{abstract}
Changing of food habits and increased preference for healthy meals, along with the growth of breakfast industry has increased the size of "ready-made" and instant porridge market in Serbia. Porridges dominantly marketed are those based on oats. However, there is a growing interest of local producers to use other cereals for porridge production. Therefore, this work was aimed to estimate the porridge-making ability of spelt wheat (Triticum aestivum spp. spelta) in comparison to that of oats. The studied porridges are instant products, based on extruded spelt or oat flour. The proximate composition, hydration properties (water absorption index-WAI and water solubility index$\mathrm{WSI}$ ), consistency and thermal properties were determined with the aim to compare the characteristics of the porridges.

In general, the spelt-based porridge had more total and insoluble fibpes, proteins, minerals and less available carbohydrates in comparison to the oat porridge. The spelt porridge may be eligible to bear the nutritional claim "high-fibre" which is advantageous for the market viability of the product. Both porridges had $>20 \%$ of damaged starch due to high initial content in the flours and extrusion processing of flours, though spelt-based extrudate and porridge were significantly higher in this parameter. Oat-based extrudate and porridge were higher in resistant starch content. The consistency was similar between the porridges, although spelt tended to form slightly firmer and cohesive porridge. Spelt porridge had better hydration properties (higher WAI) which are a featured attribute for this kind of product, similarly to higher consistency values.

Spelt wheat, in its extruded form, is a suitable ingredient for porridge production.
\end{abstract}

Key words: porridge, spelt, oats, hydration, composition, consistency, gelatinization

\section{INTRODUCTION}

Porridge is a traditional and staple food in many countries, especially developing ones. In modern cultures, porridge is enjoying a revival as a healthy breakfast food. Porridge is a convenient food for weaning infants, elderly and convalescents due to easy digestibility (Rhim et al., 2011). It is also very useful food for military troops as it can be produced to be light in weight and long in shelf-life which makes it convenient for operational pack rations (Khan et al., 2014) and in the case of food emergency situations. Traditional porridges in developing countries are based on local staple cereals (wheat, rice, millet, sorghum, maize) and starchy tubers (cassava, potato and plantain). Cerealbased porridges are usually prepared by cooking of cracked or previously soaked grains. In Northern Europe and North America, porridge is usually made from oats cooked in water and/or milk but it can 
be prepared from maize, barley and rice as well. Depending on the proportion of the cereals and liquid, two types of porridges prepared for consumption can be distinguished: thick and thin porridges. Thick porridges are solid-like and can be eaten with spoon or hand whereas thin porridge or gruel is consumed by drinking as having fluid or semi-fluid consistency (Moussa et al., 2011). Thin porridge is usually used as a complementary meal for infants.

Today, development of food processing technologies enabled the production of „ready-made" porridges which do not need long preparation and are convenient for use. Oats for porridge are processed by (hydro) thermal treatments (kilning, steaming), sizing, cutting and flaking. Different forms of porridge oats can be distinguished: pinhead (outer husk not removed), rolled oat flakes (removed outer husk, groats steamed, flattened and rolled), steel-cut oats or Irish oats (removed outer husk, groats cut into 2-3 pieces), Scottish oatmeal (groats stonegrinded instead of steel cut). Rolled oat flakes can be regular, quick (thinner flakes, more steamed) or instant (pre-cooked, rolled even thinner, dehydrated).

Extrusion cooking is a processing technology widely used to produce "ready-to-eat" breakfast cereals, expanded snacks and instant cereal-based foods. Extrusion offers many advantages to processors: high throughput, energy efficiency, thermal control, short processing time and ability to incorporate wide variety of ingredients to the final product (Eastman et al., 2001). Extrusion is a convenient way to produce instant cereal porridges which require minimum preparation time-simple, quick reconstitution with warm or cold water or milk.

In recent times, porridge has become a popular meal in Serbia. Prevalent porridges are those based on oats and they are usually sold in retail markets in the form of pre-made (sweetened and flavoured) instant porridges. However, there is an interest of local producers of organic cereals to produce porridges from other cereals like spelt wheat. Therefore, in this work, a comparison was made between the quality parameters of spelt and oat instant porridges, in order to evaluate the feasibility of spelt wheat for this product type. The instant porridges were based on extruded spelt and oat flour and were formulated to bear a "high-protein" nutritional claim (min. 20\% energy comes from protein (Regulation (EC) No. 1924/2006)).

\section{MATERIALS AND METHODS}

\section{Materials}

Spelt and oat flours and extrudates were kindly donated from local producer "BioLutisa"d.o.o., Mošorin, Serbia. The whole grain flours were obtained by abrasive milling on a stone grinder mill, after thorough cleansing and dehulling of grains. The grinded material was sifted and flour fraction between 180 and 350 $\mu \mathrm{m}$ was used to produce extrudates. Extrusion was performed on a single-screw extruder under the following processing parameters: temperature $180^{\circ} \mathrm{C}$, time 150 $\mathrm{s}$, pressure $150 \mathrm{bar}$, shear rate $\geq 100 \mathrm{~s}^{-1}$, screw rotating speed $500 \mathrm{rpm}$ and energy consumption $1.8 \mathrm{MJ} / \mathrm{kg}$. After extrusion, extrudates were ground on a hammer mill.

High-protein dry instant porridges were finally prepared by blending the grinded extruded spelt or oat with other ingredients following the proportion in the formulation: extrudate $(100 \mathrm{~g})$, oat flakes $(23.1 \mathrm{~g})$, soy protein isolate $(23.1 \mathrm{~g})$, caseine $(23.1 \mathrm{~g})$, and xylitol $(23.1 \mathrm{~g})$. The other ingredients used in porridge formulation were procured from local food stores and their origin is as follows: oat flakes "Italico", Bečej, Serbia; soy protein isolate "Yucheng Crown Soya Protein Foods Co." Ltd., China; Na-caseinate Rovita FN 5 S "Rovita" $\mathrm{GmbH}$, Germany, xylitol "Danisco Cultor AG", Switzerland.

Reconstituted porridge was prepared by pouring over the dry porridge blend with warm water $\left(50^{\circ} \mathrm{C}\right)$ at 1:2.5 (w/w) dry blend : water ratio. After vigorous mixing, the porridge was given 10 min to rest and swell.

Proximate analysis and damaged/resistant starch content

Proximate composition of samples of raw flour, extrudates and dry porridge blends were analysed according to AOAC (2000) 
standard methods: moisture (No. 926.5), ash (No. 930.22), crude proteins (No. 950.36), fat (No. 935.38), dietary fibres (No. 958.29). Carbohydrates were obtained by calculation according to $\mathrm{FAO} / \mathrm{WHO}$ guidelines using the equations 1 and 2 (FAO, 2003):

Total carbohydrates $(\mathrm{g} / 100 \mathrm{~g})=100-($ protein + fat + water + ash + alcohol)

Available carbohydrates $(g / 100 \mathrm{~g})=100$ (protein+ fat + water + ash + alcohol + total fibre)

Damaged and resistant starch contents of the samples were determined according to procedures given in the Damaged Starch and Resistant Starch Assay Kits (Megazyme International Ltd., Wicklow, Ireland).

\section{Determination of hydration properties}

Water absorption index (WAI) and water solubility index (WSI) were the parameters to describe the hydration properties of porridges. WAI and WSI of the porridges were determined as outlined in Yadav et al. (2014) and Mandge et al. (2014). $3 \mathrm{~g}$ of sample was dispersed in $30 \mathrm{ml}$ distilled water at room temperature and gently stirred. After $30 \mathrm{~min}$ hydration, the dispersion was centrifuged at $3000 \times \mathrm{g}$ for 10 min. Supernatant was carefully decanted into weighted evaporated dish and dried to constant mass at $110{ }^{\circ} \mathrm{C}$. The remaining gel was weighed and WAl $(\mathrm{g} / \mathrm{g})$ was expressed as the ratio of gel weight and dry weight of sample. WSI (\%) was expressed as the percentage of dried supernatant in dry weight of sample.

\section{DSC measurements}

DSC studies of oat/spelt flour, grinded extrudate and dry porridge blend samples were performed on a differential scanning calorimeter DSC 204F1 Phoenix (Netzsch, Germany). Approximately $3 \mathrm{mg}$ of sample was weighed into an Al crucible. Distilled water was added with a microsyringe to reach a water-to-dry solid ratio of 2.5:1 $(\mathrm{w} / \mathrm{w})$. The crucible was sealed with a lid and left to equilibrate overnight at room temperature. The equilibrated sample was then heated in the temperature range 30$120{ }^{\circ} \mathrm{C}$ with a heating rate $3{ }^{\circ} \mathrm{C} / \mathrm{min}$. From the receiving thermograms, the onset $\left(T_{0}\right)$, peak $\left(T_{p}\right)$ and endset $\left(T_{e}\right)$ gelatinization temperatures and enthalpy of gelatinezation $(\Delta \mathrm{H})$ were determined. Gelatinization temperatures and enthalpy changes were calculated using Proteus Thermal Analysis software (Netzsch, Germany).

\section{Determination of textural properties}

A Texture Analyser (TA-XTplus, SMS, Godalming, England) was used to measure the consistency and cohesiveness of the samples according to the back-extrusion method. Measurements were performed in a beaker in which the samples were mixed with warm water as explained above (paragraph Materials). A 35- $\mathrm{mm}$ disc probe was used to penetrate the samples. All measurements were made in five replications after cooling of the samples to feeding temperatures $\left(37^{\circ} \mathrm{C}\right)$. An indicator of firmness was an area under the curve registered during the penetration of the probe into the sample. Cohesiveness was measured as a peak force registered upon the probe return and it is actually an indication of the sample's resistance to flow off of the disc. The test settings were: test speed $1.0 \mathrm{~mm} / \mathrm{s}$, trigger force $10 \mathrm{~g}$ and travel distance $30 \mathrm{~mm}$.

\section{Statistical analysis}

Experimental data were statistically analysed by means of one-way ANOVA followed by Tukey's (HSD) post-hoc test and considering significant values at $\mathrm{p} \leq 0.05$ (software Statistica 13, Tulsa, OK).

\section{RESULTS AND DISCUSSION}

\section{Composition}

Spelt flour had higher content of proteins, ash, total and insoluble fibres in comparison to oat flour which was higher in fat and soluble fibre content (Table 1). These relations remained similar after extrusion of the flours and in the formulated porridges. Higher ash content in spelt flour and extrudates imply to higher content of minerals. The damaged starch content was similarly high in both oat and spelt flour (around 25\%), probably due to grinding on a stone mill. Interestingly, extrusion did not increase the damaged starch content. In contrast, resistant starch content increased after extrusion of oat flour but decreased in the case of spelt 
flour. The formation of resistant starch during extrusion depends on the moisture content and extrusion variables (Núňez et al., 2009). Even minor changes of process parameters which affect starch gelatinization and retrogradation may induce huge differences in the resistant starch content in food (Perera et al., 2010). Spelt flour, extrudate and porridge contained less available carbohydrates in comparison to those of oats but slightly higher content of damaged starch and less resistant starch. The lower available carbohydrate content may be favourable in formulating diets with lower dietary carbohydrates but the presence of damaged starch and less resistant starch may be less favourable regarding glycaemic impact. Resistant starch is not digested in the human small intestine but is fermented in the large bowel providing numerous health-beneficial effects such as reduction in the glycaemic response, cholesterol reducing effect and anticarcinogenic effect in colon (Asp et al., 1992). On the other hand, damaged (gelatinized) starch is more susceptible to digestion. Starch digestion and consequently, the metabolic response, depends on many factors including starch gelatinization degree, presence of indigestible polymers (dietary fibres), proteins. etc. (Granfeldt et al., 1992). To predict the real glycaemic impact of spelt and oat porridges, it is required to study the digestible and indigestible fractions of starch in more detail. The porridge based on spelt may be labelled "high-fibre" as it provides $>6 \mathrm{~g}$ of fibres per $100 \mathrm{~g}$ whereas oat porridge may bear the nutritional claim "source of fibre“ according to Nutritional Claims for food (Regulation (EC) No. 1924/2006 lastly amended by Regulation (EU) No $1047 / 2012)$. Oat is rich in beneficial soluble fibre, beta-glucan, which also subjects to labelling and is additionally advantageous feature to increase the market viability (Regulations (EU) No. 432/2012).

\section{Hydration properties}

WAI indicates the hydration properties of materials in excess water and is generally attributed to the ability of starch to absorb water or, indirectly, the proportion of intact and gelatinized starch. Actually, it depends on the availability of hydrophilic groups to bind water molecules and on the gel forming capacity of macromolecules (Mandge et al., 2014). WAl was observed to increase with higher starch content (Gandhi and Singh, 2015). Gelatinized starch and starch damaged by extrusioninduced fragmentation increases WAI (Rayas-Duarte et al., 1988). WAl can also be affected by protein macromolecules as observed by Mandge et al. (2014) who reported that instant multigrain porridge increased WAI when processed at higher temperatures, causing denaturation of proteins. WSI reflects on the degree of starch degradation as it measures low molecular weight molecules dissolved in the water (Kirby et al., 1988). WSI can be a predictor of the susceptibility of food to digestion which is important in designing weanening food for infants (Nguyen et al., 2010). Flours of spelt and oat showed similar WAI values (1.22 and $1.33 \mathrm{~g} / \mathrm{g}$, respectively) whereas spelt flour had higher WSI $(7.09 \%)$ than the oat flour $(3.73 \%)$. After extrusion, WAI and WSI in oat and spelt significantly increased. Earlier reports suggest that WAI and WSI tend to increase after extrusion process (Ding et al., 2005; Jozinović et al., 2016). Jozinović et al. (2016) related a post-extrusion increase in WAI and WSI with starch damage in corn grits extrudates. Higher WAI in porridges is affirmative for the production of thick porridges for people on weight-reducing diet because it would provide adequate, thick consistency porridge but with less calories per a portion. The porridges had higher WSI in comparison to the corresponding extrudates probably due to presence of other ingredients in their formulation.

\section{Thermal analysis}

DSC results for the spelt/oat flours and extrudates are displayed in Tab. 3 and Fig. 1. Oat and spelt flours showed a characteristic gelatinization peak (Fig. 1) which results from the gelatinization of the starch granules in excess water, caused by the melting of crystalline structure of starch. Oat flour showed lower onset, peak and endset temperatures in comparison to the spelt flour which is attributable to differences in the structure and crystallinity bet- 
ween the oat and spelt wheat starches. Oat starch granules are the smallest in comparison to other cereals, which also affects the pasting properties (Zhou et al., 1998). The observed melting enthalpies for oat and spelt (Tab. 3) are lower than those reported by other researchers (Núňez et al., 2009; Gałkowska et al., 2014) but this might be due to the fact that the results reported here are not expressed in grams of starch. After extrusion, the endothermic peak disappeared (Fig. 1) for both spelt and oat, suggesting that starch underwent complete gelatinezation and that starch granules were fully disrupted. This is in line with the DSC thermographs of cereal and pseudocereal flours after extrusion reported by Robin et al. (2015). However, in oat and spelt extrudates, around $24 \%$ damaged (gelatinized) starch was measured by enzymatic method (Tab. 1) which was in contrast to DSC data that suggested $100 \%$ gelatinezation. Since the content of available carbohydrates is $65-69 \%$, theoretically, the remaining $40-45 \%$ could account for su- gars and the rest of starch. Zhu et al. (2016) reported discrepancies in estimation of starch gelatinization degree between DSC method and enzymatic method, observing that DSC method tended to produce overestimated results.

\section{Textural properties}

Aqueous slurries of oat and spelt flours were flowable and showed little resistance to back-extrusion force. The difference in consistency between spelt and oat porridge was not statistically significant ( $p>0.05$ ) although spelt porridge tended to form a firmer and more cohesive porridge (Fig. 3).

In contrast, the paste of extruded flours showed remarkable increase in firmness and cohesiveness due to increased water absorption capacity. Oat extrudates showed an ability to form a cohesive mass. Higher firmness and viscosity is a desirable property in porridges (Yadav et al., 2014) but quantitative guidelines on the acceptable consistency of porridge does not exist (de Carvalho et al., 2014).

Table 1.

Proximate composition, damaged and resistant starch contents of the oat and spelt flours, extrudates and porridges $\left({ }^{a-e}\right.$ Marks with different letters in the same row indicate statistical significance at $\left.p<0.05\right)$

\begin{tabular}{lcccccc}
\hline \multirow{2}{*}{$\begin{array}{l}\text { Parameter } \\
\text { (\% d.m.) }\end{array}$} & \multicolumn{2}{c}{ Flour } & \multicolumn{2}{c}{ Extrudate } & \multicolumn{2}{c}{ Dry porridge blend } \\
\cline { 2 - 7 } & Oat & Spelt & Oat & Spelt & Oat & Spelt \\
\hline Moisture & $11.48 \pm 0.11^{\mathrm{d}}$ & $11.67 \pm 0.10^{\mathrm{d}}$ & $7.41 \pm 0.05^{\mathrm{a}}$ & $9.96 \pm 0.08^{\mathrm{c}}$ & $7.34 \pm 0.04^{\mathrm{a}}$ & $8.37 \pm 0.04^{\mathrm{b}}$ \\
Ash & $1.83 \pm 0.07^{\mathrm{a}}$ & $2.29 \pm 0.09^{\mathrm{b}}$ & $2.16 \pm 0.08^{\mathrm{b}}$ & $2.62 \pm 0.13^{\mathrm{c}}$ & $2.62 \pm 0.11^{\mathrm{c}}$ & $3.31 \pm 0.10^{\mathrm{d}}$ \\
Proteins & $13.59 \pm 0.04^{\mathrm{b}}$ & $15.87 \pm 0.06^{\mathrm{c}}$ & $12.87 \pm 0.03^{\mathrm{a}}$ & $18.01 \pm 0.05^{\mathrm{d}}$ & $29.39 \pm 0.08^{\mathrm{e}}$ & $32.39 \pm 0.03^{\mathrm{f}}$ \\
Fat & $6.40 \pm 0.05^{\mathrm{e}}$ & $2.49 \pm 0.03^{\mathrm{c}}$ & $7.27 \pm 0.04^{\mathrm{f}}$ & $1.21 \pm 0.01^{\mathrm{a}}$ & $4.56 \pm 0.04^{\mathrm{d}}$ & $1.58 \pm 0.02^{\mathrm{b}}$ \\
Total fibres & $6.58 \pm 0.02^{\mathrm{b}}$ & $10.16 \pm 0.05^{\mathrm{d}}$ & $8.70 \pm 0.04^{\mathrm{c}}$ & $12.87 \pm 0.05^{\mathrm{e}}$ & $5.37 \pm 0.02^{\mathrm{a}}$ & $8.89 \pm 0.03^{\mathrm{c}}$ \\
$\quad$ Insoluble fibres & $4.35 \pm 0.01^{\mathrm{b}}$ & $8.15 \pm 0.04^{\mathrm{e}}$ & $5.48 \pm 0.03^{\mathrm{c}}$ & $10.01 \pm 0.05^{\mathrm{f}}$ & $3.43 \pm 0.02^{\mathrm{a}}$ & $6.72 \pm 0.04^{\mathrm{d}}$ \\
$\quad$ Soluble fibres & $2.23 \pm 0.01^{\mathrm{b}}$ & $2.01 \pm 0.012^{\mathrm{a}}$ & $3.22 \pm 0.018^{\mathrm{d}}$ & $2.86 \pm 0.02^{\mathrm{c}}$ & $1.93 \pm 0.017^{\mathrm{a}}$ & $2.17 \pm 0.01^{\mathrm{b}}$ \\
Total carbohydrates & $78.18 \pm 0.27^{\mathrm{d}}$ & $79.35 \pm 0.28^{\mathrm{e}}$ & $77.70 \pm 0.20^{\mathrm{c}}$ & $78.16 \pm 0.27^{\mathrm{d}}$ & $63.43 \pm 0.27^{\mathrm{b}}$ & $62.72 \pm 19^{\mathrm{a}}$ \\
by calculation & & & & & & \\
Available carbohyd. \\
by calculation
\end{tabular}

Table 2.

Gelatinization temperature and enthalpy of the oat and spelt flours. $\left({ }^{a-b}\right.$ Marks with different letters in the same column indicate statistical significance at $p<0.05$ )

\begin{tabular}{lcccc} 
Sample & $\mathbf{T}_{\mathrm{o}}$ & $\mathbf{T}_{\mathrm{p}}$ & $\mathbf{T}_{\mathrm{e}}$ & $\Delta \mathbf{H}$ \\
& $\left({ }^{\circ} \mathrm{C}\right)$ & $\left({ }^{\circ} \mathrm{C}\right)$ & $\left({ }^{\circ} \mathrm{C}\right)$ & $(\mathrm{J} / \mathrm{g} \mathrm{d} . \mathrm{m})$. \\
\hline Oat flour & $55.4 \pm 0.3^{\mathrm{a}}$ & $62.0 \pm 0.2^{\mathrm{a}}$ & $67.6 \pm 0.1^{\mathrm{a}}$ & $6.4 \pm 0.5^{\mathrm{a}}$ \\
Spelt flour & $61.7 \pm 0.2^{\mathrm{b}}$ & $65.1 \pm 0.1^{\mathrm{b}}$ & $69.2 \pm 0.2^{\mathrm{b}}$ & $5.2 \pm 0.4^{\mathrm{b}}$ \\
\hline
\end{tabular}




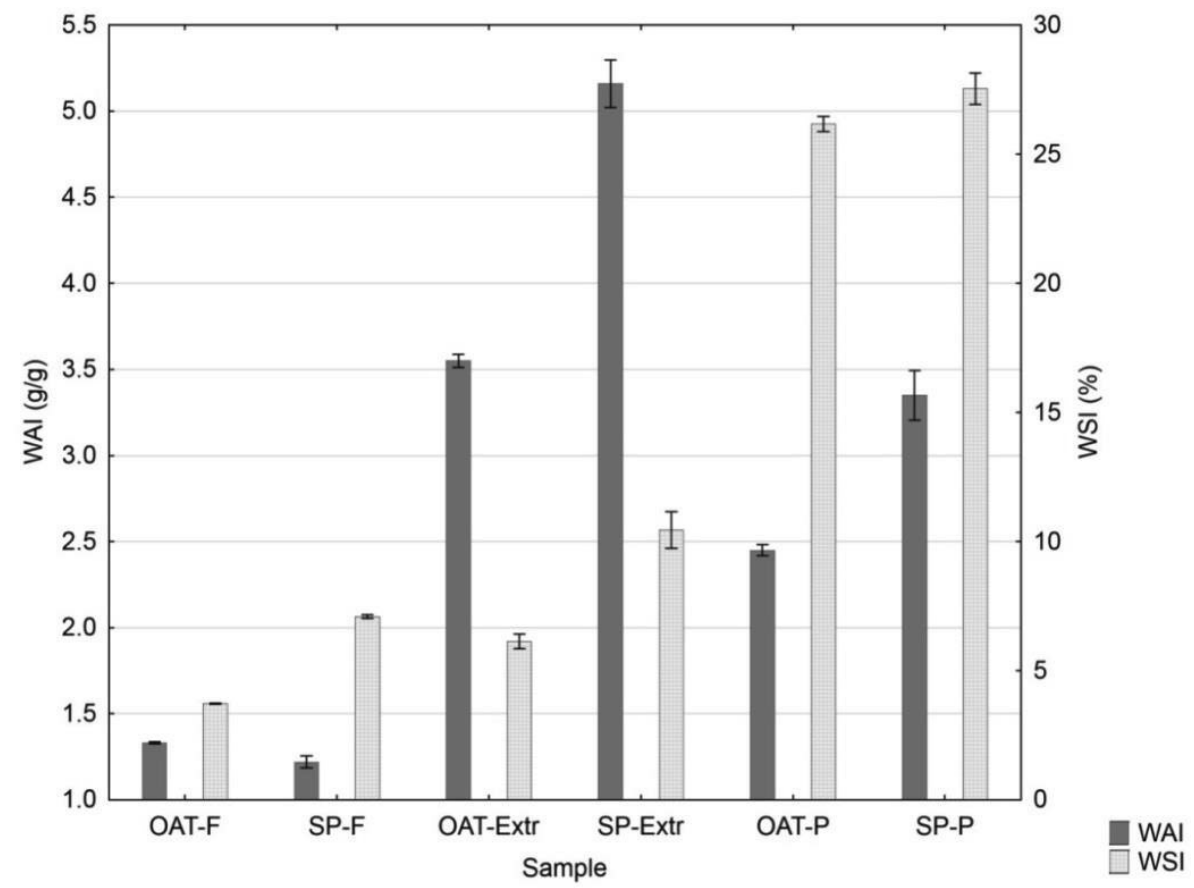

Figure 1. Water absorption index (WAI) and water solubility index (WSI) of oat and spelt flour, extrudates and porridges

a) spelt

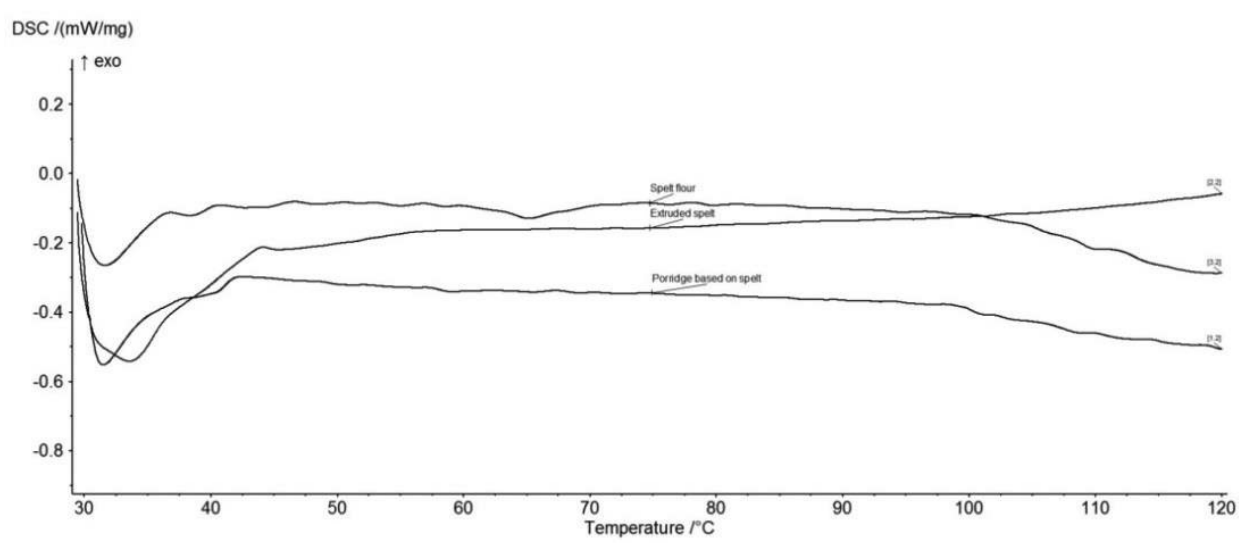

b) oats

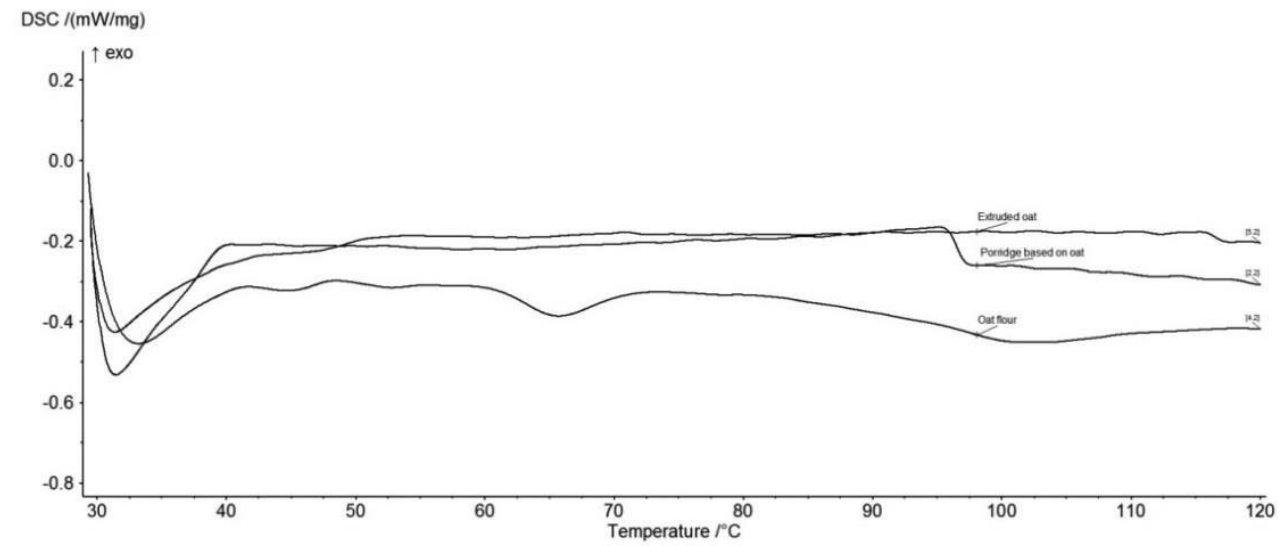

Figure 2. DSC Thermograms of oat and spelt flour before and after extrusion and corresponding porridges 


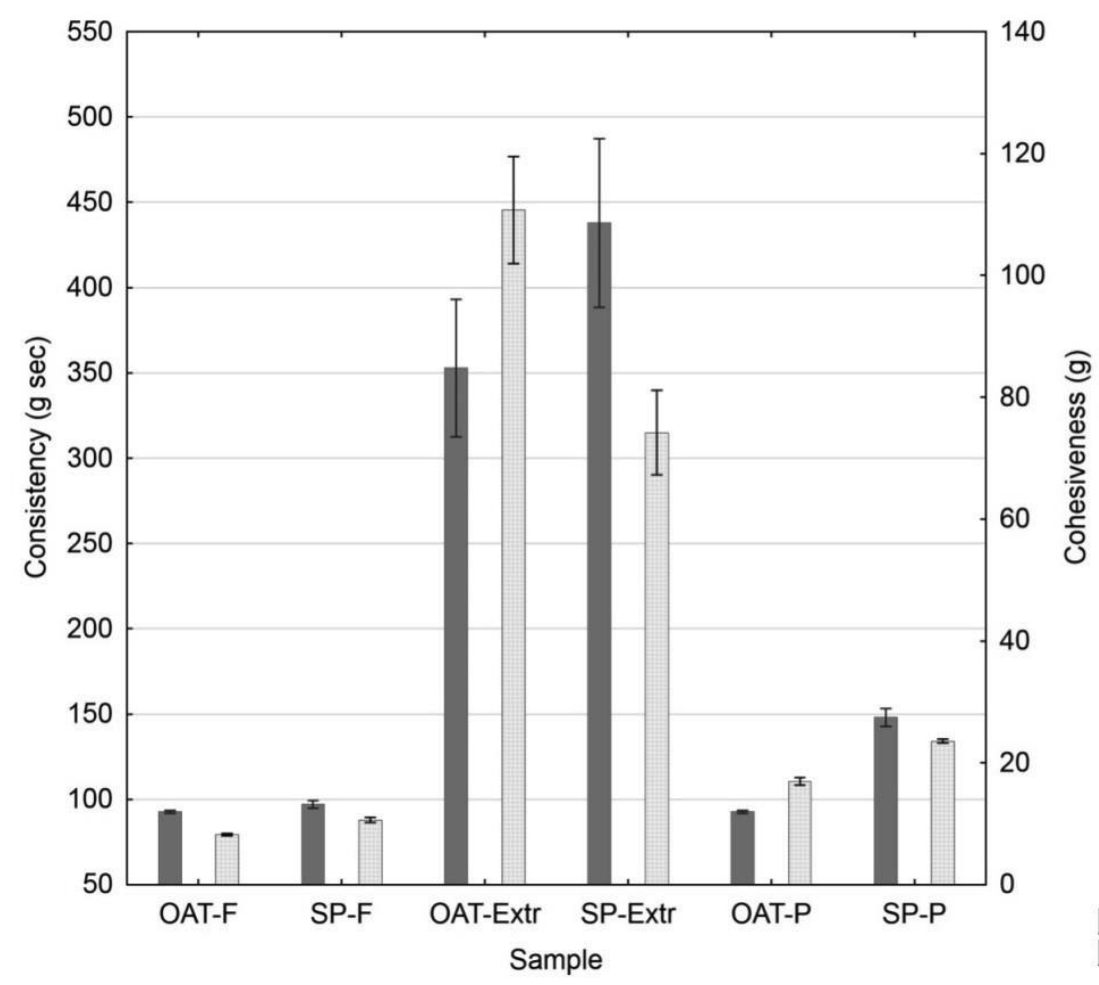

Consistency

Cohesiveness

Figure 3.Consistency of aqueous slurries of spelt and oat flour and reconstituted extrudates/porridges

WHO guideline recommends that porridge should not drip from a spoon (WHO, 2000). Rebello et al. (2014) noted that high initial viscosity of instant oatmeal was associated with increased satiety and consequently, better efficiency of appetite control. Joshi et al. (2014) reported that textural properties of starch-protein composite gel/paste are strongly dependent on the ratio of starch and protein as well as on several extrinsic factors $(\mathrm{pH}$, ionic strength, reducing agents, etc.).

\section{CONCLUSION}

The results of this comparative study showed that instant oat and spelt porridges based on extruded oat and spelt flour shared similar features yet some differences were observed. The spelt extrudate and instant porridge had more total and insoluble fibres, proteins and minerals as well as less available carbohydrates in comparison to the oat porridge. Oat extrudate and porridge were higher in soluble fibre and fat. Based on the amount and type of fibres found in the extrudates/porridges, spelt porridge may bear a label „high-fibre“ whereas oat porridge may be labelled as "source of fibre". The flours had similar level of starch damage whereas spelt extrudates and porridge were significantly higher in damaged starch in relation to the oat-based extrudate and flour. Oat flour, extrudate and porridge were higher in resistant starch. Hydration properties of spelt extrudate and porridge were better in comparison to those of oats. Relatively high amounts of damaged (gelatinized) starch were found in both porridges (>20 g/100 g d.b.) which is due to high initial content in flour and extrusion processing. The spelt porridge and extrudate had somewhat firmer consistency than the oat porridge and extrudate but statistical significance was not reached. Oat extrudate was capable of forming a cohesive mass. Higher hydration capacity, firmness and cohesiveness are desirable attributes in porridges.

\section{ACKNOWLEDGEMENTS}

The authors acknowledge the financial support from the Ministry of Education, Science and Technological Development of Republic of Serbia for this work which is the part of project III 46005. 


\section{REFERENCES}

1. AOAC (2000). Official Methods of Analysis of AOAC International, $17^{\text {th }}$ Ed., Association of Analytical Chemists, Arlington, VA.

2. Asp, N.G., Van Amelsvoort, J.M.M., Hautvast, J.G.A.J. (1996). Nutritional implications of resistant starch. Nutrition Research, 9, 1-31.

3. De Carvalho, I.S.T., Granfeldt, Y., Eliasson, AC., Dejmek, P. (2014). Predictability of the consistency of porridges using different methods to measure flour swelling. Starch/Stärke, 66, 199-207.

4. Ding, Q.B., Ainsworth, P., Tucker, G., Marson, $H$. (2005). The effect of extrusion conditions on the physicochemical properties and sensory characteristics of rice-expanded snacks. Journal of Food Engineering, 66 (3), 283-289.

5. Eastman, J., Orthoefer, F., Solorio, S. (2001). Using extrusion to create breakfast cereal products. Cereal Foods World, 46 (10), 468471.

6. FAO (2003). Methods of food analysis. In Food energy - methods of analysis and conversion factors. FAO FOOD AND NUTRITION PAPER 77, Report of a Technical Workshop, Rome, 36, December 2002, Food And Agriculture Organization of the United Nations, Rome. Retrieved on Feb. 2017, from http://www.fao.org/docrep/006/Y5022E/y5022e 03.htm\#bm3.

7. Gałkowska, D., Witczak, T., Korus, J., Juszczak, L. (2014). Characterization of some spelt wheat starches as a renewable biopolymeric material. ISRN Polymer Science, 2014, ID 361069, 9 pages, DOI: 10.1155/2014/361069.

8. Gandhi, N., Singh, B. (2015). Study of extrusion behaviour and porridge making characteristics of wheat and guava blends. Journal of Food Science and Technology, 52 (2), 3030-3036.

9. Granfeldt, Y., Björck, I., Drews, A., Tovar, J. (1992). An in vitro procedure based on chewing to predict metabolic response to starch in cereal and legume products. European Journal of Clinical Nutrition, 46, 649-660.

10. Joshi, M., Aldred, P., Spanozzo, J.F., Kasapis, S., Adhikari, B. (2014). Rheological and microstructural characteristics of lentil starch-lentil protein composite pastes and gels. Food $\mathrm{Hy}$ drocolloids, 35, 226-237.

11. Jozinović, A., Šubarić, D., Ačkar, Đ., Babić, J., Miličević, B. (2016). Influence of spelt flour addition on properties of extruded products based on corn grits. Journal of Food Engineeering, 172, 31-37.

12. Khan, M.A., Semwal, A.D., Sharma, G.K., Bawa, A.S. (2014). Studies on the optimization and stability of instant wheat porridge (Dalia) mix. Journal of Food Science and Technology, 51 (6), 1154-1160.

13. Kirby, A.R., Ollett, A.L., Parker, R., Smith, A.C. (1988). An experimental study of screw configuration effects in the twin srew extrusion cooking of maize grits. Journal of Food Engineering, 8, 247-272.

14. Mandge, H.M., Sharma, S., Nabi Dar, B. (2014). Instant multigrain porridge: effect of co- oking treatment on physicochemical and functional properties. Journal of Food Science and Technology, 51 (1), 97-103.

15. Moussa, M., Qin, X., Chen, L-F., Campanella, O.H., Hamaker, B.R. (2011). High-quality instant sorghum porridge flours for the West African marekt using continuous processor cooking. International Journal of Food Science and Technology, 46, 2344-2350.

16. Neder-Suárez, D., Amaya-Guerra, C.A., Quintero-Ramos, A., Pérez-Carrillo, E., de J. AlanísGuzmán, M., Báez-González,J.G.,García-Díaz, C.L., Núñez-González, M. A., Lardizábal-Gutiérrez, D., Jiménez-Castro, J.A. (2016). Physicochemical changes and resistant-starch content of extruded cornstarch with and without storage at refrigerator temperatures. Molecules, 21, 1064, DOI: 10.3390/molecules21081064.

17. Nguyen, $\mathrm{VH}$; Mouquet-Rivier, C; Treche, S. (2010). Effects of starch, lipid and moisture contents on extrusion behavior and extrudate characteristics of rice-based blends prepared with a very-low-cost extruder. Journal of Process Engineering, 33, 519-539.

18. Núňez, M., Sandoval, A.J., Müller, A.J., Della Valle, G., Lourdin, D. (2009). Thermal characterization and phase behavior of a ready-toeat breakfast cereal formulation and its starchy components. Food Biophysics, 4, 291-303.

19. Perera, A., Meda, V., Tyler, R.T. (2010). Resistant starch: A review of analytical protocols for determining resistantstarch and of factors affecting the resistant starch content of foods. Food Research International, 43, 1959-1974.

20. Rayas-Duarte, P., Majewska, K., Doetkott, C. (1998). Effect of extrusion process parameters on the quality of buckwheat flour mixes. Cereal Chemistry, 75, 338-345.

21. Rebello, C.J., Chu, Y-F., Johnson, W.D., Martin, C.K., Han, H., Bordenave, N., Shi, Y., O'Shea, M., Greenway, F.L. (2014). The role of meal viscosity and oat $\beta$-glucan characteristics in human appetite control: a randomized crossover trial. Nutrition Journal, 13, 49, DOI: 10.1186/1475-2891-13-49.

22. Regulation (EC) No. 1924 (2006). Regulation (EC) No $1924 / 2006$ of the European Parliament and of the Council of 20 December 2006 on nutrition and health claims made on foods. The Official Journal of EU, Series $L$ 404, 30.12.2006, p. 9

(https://ec.europa.eu/food/safety/labelling nutrit ion/claims/nutrition claims en).

23. Regulation (EU) No. 432 (2012). COMMISSION REGULATION (EU) No 432/2012 of 16 May 2012 establishing a list of permitted health claims made on foods, other than those referring to the reduction of disease risk and to children's development and health. The Official Journal of EU, Series L 136, 25.05.2012, p. 5. (https://www.fsai.ie/uploadedFiles/Reg432 201 2.pdf).

24. Regulation (EU) No. 1047 (2012). The Official Journal of EU, Series L 310, 09.11.2013, p. 3637. (http://data.europa.eu/eli/reg/2012/1047/oj).

25. Rhim, J.W., Koh, S., Kim, J.M. (2011). Effect of freezing temperature on rehydration and water 
vapor adsorption characteristics of freeze-dried rice porridge. Journal of Food Engineering, 104, 484-491.

26. Robin, F., Théoduloz, C., Srichuwong, S. (2015). Properties of extruded whole grain cereals and pseudocereals flours. International Journal of Food Science and Technology, 50, 2152-2159.

27. WHO (2000). Complementary feeding: Family foods for breastfed children, Department of Nutrition for Health and Development, France.
28. Yadav, D.N., Chhikara, N., Anand, T., Sharma, M., Singh, A.K. (2014). Rheological quality of pearl millet porridge as affected by grits size. Journal of Food Science and Technology, 51 (9), 2169-2175.

29. Zhu, L., Jones, C., Guo, Q., Lewis, L., Stark, C.R., Alavi, S. (2016). An evaluation of total starch and starch gelatinization methodologies in pelleted animal feed. Journal of Animal Science, 2016.94, 1501-1507, DOI: 10.2527/jas2015-9822.

\title{
УПОРЕДНА ИСПИТИВАҢА ФИЗИЧКО-ХЕМИЈСКИХ, ТЕКСТУРНИХ И ТЕРМИЧКИХ СВОЈСТАВА ИНСТАНТ КАША ОД СПЕЛТА ПШЕНИЦЕ И OBCA
}

\author{
Оливера Д. Шимурина“, Бојана В. Филипчев, Бошко Д. Марић, Биљана Р. Цветковић, Марија И. \\ Бодрожа Соларов
}

Универзитет у Новом Саду, Научни институт за прехрамбене технологије у Новом Саду, 21000 Нови Сад, Бул. цара Лазара 1, Србија

Сажетак: Промене у начину исхране и изражена склоност потрошача према здравој храни уз раст сектора производње хране за доручак је довео до повећања понуде готових и инстант каша на домаћем тржишту. На домаћем тржишту су претежно заступљене каше од овса. Међутим, постоје домаћи произвођачи који су заинтересовани да производе каше од других жита. У складу са овом тенденцијом, циљ овог рада јесте да упореди квалитетна својства инстант каша на бази спелта пшенице и овса и на тај начин да увид у потенцијал спелта пшенице за производњу ове врсте производа. Испитиване каше су инстант производи, направљени од екструдиране спелте и овса. Да би се упоредила квалитетна својства каша од спелте и овса, извршено је испитивање хемијског састава, хидратационих својстава (моћ апсорпције воде и индекс растварања у води), конзистенције и термичких својстава.

У просеку, каша од спелте је садржала више укупних и нерастворљивих влакана, протеина, минералних материја и расположивих угљених хидрата у односу на овсену кашу. Каша од спелте може да се декларише као производ са високим садржајем влакана, што може позитивно да се одрази на комерцијализацију производа. Обе испитиване каше садржале су сличне високе садржаје оштећеног скроба што је последица коришћења екструдираног брашна у њиховој формулацији. Конзистенције каша су биле сличне, с тим да је каша од спелте имала већу чврстоћу и кохезивност, али статистички значајна разлика није утврђена. Каша од спелте је имала боља хидратациона својства (већа моћ упијања воде), што је једна од пожељних особина, уз веће вредности за конзистенцију и кохезивност, код ове врсте производа.

Спелта пшеница у екструдираној форми је погодна за производњу квалитетне инстант каше. зација

Кључне речи: каша, спелта, овас, хидратација, састав, конзистенција, желатини-

Received: 19 April 2018

Received in revised form: 14 May 2018

Accepted: 22 May 2018 